УДК 811.581

doi: 10.22250/2410-7190_2021_7_4_16_28

\author{
Васина Ксения Сергеевна, Тё Ольга Евгеньевна \\ Московский Государственный Технический Университет имени Н. Э. Баумана \\ г. Москва, Российская Федерация \\ tyo_olga@bmstu.ru

\section{Неологизмы в общественно-политических текстах на китайском языке в период пандемии коронавируса (COVID-19)}

\begin{abstract}
Аннотация
В данной статье представлен анализ неологизмов, которые возникли в китайском языке в период пандемии коронавируса. Любые перемены, происходящие в социуме, в первую очередь отображаются на страницах общественно-политических СМИ, поэтому в качестве материала исследования были отобраны новостные публикации из влиятельных СМИ Китая (газета «Жэньминь жибао», информационное агентство «Синьхуа», газета «Гуанмин жибао» и др.), которые пользуются огромным доверием у народа. Цель исследования - определить особенности формирования и специфику использования новых слов и выражений в период 6-8 месяцев с момента начала пандемии. В ходе работы было проанализировано около 500 статей о коронавирусной инфекции, в результате чего выявлено более 30 неологизмов. В статье представлен подробный анализ 10 самых частотных неологизмов, которые были реализованы в 289 контекстах. В результате выявлено, что наиболее продуктивным словообразовательным способом оказалось словосложение (60\%); наименее продуктивным - приобретение дополнительной коннотации $(30 \%)$; самым редким - омофония (10\%).
\end{abstract}

Ключевые слова: неологизмы, китайский язык, словообразование, словосложение, новые коннотации, заимствования, омофония

(C) Васина К. С., Тё О. Е. 2020

Для цитирования: Васина К. С., Тё О. Е. Неологизмы в общественно-политических текстах на китайском языке в период пандемии коронавируса (COVID-19) // Теоретическая и прикладная лингвистика. 2021. Вып. 7, № 4. С. 16-28. https://doi.org/10.22250/2410-7190_2021_7_4_16_28

\author{
Ksenia S. Vasina, Olga E. Te ${ }^{凶}$ \\ Bauman Moscow State Technical University \\ Moscow, Russian Federation \\ tyo_olga@bmstu.ru
}

\title{
Neologisms in socio-political texts in Chinese during the coronavirus (covid-19) pandemic
}

\begin{abstract}
This article examines neologisms that emerged in the Chinese language during the coronavirus pandemic. Any changes taking place in society are primarily reflected in social and political media, therefore, news publications in influential Chinese media (People's Daily, Xinhua News Agency, Guangming Daily) were selected as the research material because these sources enjoy the confidence among people. The aim of the research is to determine the building patterns and usage of neologisms that appeared during the period of 6-8 months since the pandemic outbreak. About 500 articles discussing coronavirus were analyzed in the course of the work, as a result, more than 30 neologisms were identified. In this paper, we present a detailed analysis of 10 most frequent neologisms found in 289 contexts. It was discovered that compounding was the most frequent neologism-
\end{abstract}


building pattern $(60 \%)$, additional connotation acquisition turned out twice less frequent $(30 \%)$, and the rarest pattern was homophony (10\%).

Keywords: neologisms, Chinese language, word-building patterns, compounding, loanwords, new connotations, homophony

(c) Vasina K. S., Te O. E. 2021

For citation: Vasina, K. S., Te, O. E. Neologizmy v obshchestvenno-politicheskikh tekstakh na kitayskom yazyke v period pandemii koronavirusa (COVID-19) [Neologisms in socio-political texts in Chinese during the coronavirus (covid-19) pandemic]. Teoreticheskaya $i$ prikladnaya lingvistika [Theoretical and Applied Linguistics], 7 (4), 16-28. https://doi.org/10.22250/2410-7190_2021_7_4_16_28

\section{1. Введение [Introduction]}

В современном обществе изменения происходят с немыслимой скоростью. Мы живем в период глобализации, которая характеризуется в первую очередь активным развитием науки, техники, культуры, искусства. Эти перемены оказывают огромное влияние на язык, прежде всего отражаясь на его лексическом строе: язык пополняется новыми словами, которые постепенно включают в словари, и таким образом лексический запас языка в целом становится богаче. Благодаря исследованию подобных явлений в языке можно проследить и проанализировать трансформацию всех сфер жизни общества на современном этапе развития.

Как известно, некоторые слова исчезают, постепенно выходят из употребления, а другие, наоборот, появляются, начинают активно использоваться. Именно вторая категория доказывает жизнеспособность языка, его стремление выразить богатство человеческих знаний и прогресса цивилизаций. Л. Ю. Касьянова отмечала: «Новое всегда возникает в результате углубленного осмысления (переосмысления) действительности, открытия неизвестных ранее свойств и признаков познаваемых объектов. Поэтому особую значимость приобретает проблема выявления нового знания, свойственного неологизмам, специфики объективируемой в них информации» [Касьянова, 2009, с. 4].

Можно долго рассуждать о природе и причинах коронавирусной инфекции нового типа, которая потрясла всё человечество в конце 2019 года, но одно останется очевидным: мир уже не станет прежним. Пандемия коронавируса впервые в истории привела к изоляции мирового масштаба. Учёным ещё предстоит изучить этот революционный исторический период с разных точек зрения, и попытки уже активно предпринимаются, в том числе лингвистами, работающими на китайском материале (см. анализ лозунгов, напр., в работах [Дубинина, 2021 ; Ли Синь, Стародубцева, 2021]). Отмечается и высокий лингводидактический потенциал различных текстов о короновирусе и пандемии, в том числе злободневных юмористических материалов [Шамина и др., 2020]. Но если говорить в аспекте лингвистики, то неоспорим факт того, что в разных языках, и в первую очередь в китайском, произошли серьёзные изменения. В настоящей статье предпринята попытка провести анализ ряда неологизмов, которые появились и уже активно используются носителями языка на протяжении нескольких месяцев с начала пандемии.

В первую очередь необходимо определиться с терминологией. Под неологизмом (新词语, досл. «новый оборот речи»), вслед за выдающимся китаистом, лингвистом В. И. Гореловым, мы понимаем «Новые слова, которые ещё не вошли в общий активный словарный состав, не закрепились в языке, и новизна которых ощущается говорящими» [Горелов, 1984, с. 156].

Если говорить о китайском языкознании, то стоит выделить три точки зрения, которые на сегодняшний день служат основой для изучения неологизмов: 
1. Ван Текунь под неологизмами понимает в первую очередь новые лексические единицы, которые подходят по всем категориям словообразовательному процессу в китайском языке. Кроме того, он включает в этот класс все заимствованные слова, вэньянизмы (文言词: слова из классического китайского языка, сохранившего морфологию и синтаксис древнекитайского), диалектизмы [Ван, 1991, с. 10].

2. Яо Ханьмин несколько расширяет предыдущий пункт, полагая, что неологизмы - это и собственно новые слова, и те слова, которые уже давно входят в лексику языка, но приобрели новое значение в результате определенных событий [Яо, 1998, c. 8].

3. Дяо Яньбинь определяет неологизмы как те слова, которые люди вынуждены создавать для обозначения новых предметов и явлений, появившихся в ходе эволюции науки и техники [Дяо, 2003, с. 5].

В данной статье рассмотрим в первую очередь те слова, которые уже присутствовали в словарном составе китайского языка, но приобрели новые значения.

\section{2. Анализ неологизмов в период коронавирусной инфекции [Covid-19 neologisms]}

Распространение вируса COVID-19 началось с китайского города Ухань в декабре 2019 года, и уже 30 января 2020 года Всемирная организация здравоохранения (ВО3) признала вспышку нового коронавируса (COVID-19) чрезвычайной ситуацией в области общественного здравоохранения, имеющей международное значение. 11 марта 2020 года ВОЗ объявила, что распространение болезни приобрело характер пандемии, поскольку число случаев заражения в разных точках мира стало стремительно возрастать.

Невозможно оставить незамеченным тот факт, что происходящие события оказывают огромное влияние на язык: за обозначенный период лексика китайского языка пополнилась набором новых слов и выражений. По словам известного китайского социолингвиста Чэнь Юаня, китайские неологизмы первыми сигнализируют об изменениях в социальной жизни Китая [Чэнь, 1999].

Следует отметить, что средства массовой информации, являясь социальным институтом, обеспечивают важную часть информационного обмена в современном обществе. Они играют весомую роль в процессах, связанных с направляемыми социальными и политическими изменениями. Без необходимого информационного обеспечения сегодня невозможно принятие эффективных решений на всех уровнях управления государством, без достаточного потока информации трудно представить полноценную жизнь индивида в современных условиях общества.

В связи с этим было решено проанализировать статьи за 6-8 месяцев с момента начала пандемии, опубликованные ведущими СМИ Китая, среди них интернет-версии изданий «Жэньминь жибао» (人民 日 报), официального информационного агентства правительства КНР «Синьхуа» (新华), «Гуанмин жибао» (光明日报), «China Daily» и др. Все эти издания являются влиятельными источниками информации как в КНР, так и за её пределами. Из указанных СМИ неологизмы отбирались методом сплошной выборки вручную. При отборе мы ориентировались на следующие критерии: тематический и хронологический (все слова непосредственно связаны с ситуацией коронавируса и периодом пандемии); частотность употребления в текстовых реализациях и отсутствие закрепленности в лексикографических источниках (в первую очередь в электронных справочниках и словарях). Несмотря на то, что ощущение новизны, которое возникает у исследователя при восприятии определённой языковой единицы, является достаточно субъективным, этот критерий тоже учитывался. Как оказалось, в процессе отбора естественным образом происходило наложение одного критерия на другой, что формировало комплексный под- 
ход. В ходе анализа около 500 статей было выявлено более 30 неологизмов, которые были реализованы в 319 контекстах. В статье представлен подробный анализ 10 неологизмов с наиболее высокой частотностью употребления, реализованных в 289 контекстах. Для анализа неологизмов использовались методы лингвистического наблюдения и описания, контекстный анализ, семантический анализ и метод описательной статистики (простого количественного подсчёта). Перейдём к изложению полученных результатов.

В первую очередь необходимо отметить статью от 12 февраля 2020 года о появлении лексической единицы коронавирусная инфекиия нового типа в лексике китайского языка. В ней говорится о том, что 11 февраля Генеральный директор Всемирной организации здравоохранения Тедрос Аданом Гебреисус объявил о том, что новая коронавирусная пневмония будет официально названа «Коронавирусная болезнь 2019» (COVID-19) 新型冠状病毒: «CO» означает «Корона (Corona)», VI - «Вирус (Virus)», «D»- заболевание, а «19» указывает на 2019 год, когда заболевание было обнаружено. «Однако присвоение имён вирусам или болезням не всегда обстояло так. Возможно, мы слышали о некоторых известных вирусах и заболеваниях, включая «вирус Эбола» (埃博拉病毒), Ближневосточный респираторный синдром (中东呼吸综合症), болезнь Марбурга (马尔堡病), японский энцефалит (日本脑炎), немецкая корь (德国麻 疹) и др.», - сказал Тедрос Аданом Гебреисус [Лин, Лю, 2020].

Из этих методов присвоения названия можно понять следующее: все они связаны с географическими названиями. Однако, как известно, в 2015 году ВОЗ обнародовала «Руководящие принципы для обозначения вновь выявленных болезней» нейтральные, общие термины должны использоваться вместо имён людей, мест, животных, продуктов питания и профессий для обозначения болезней. По этой причине в 2003 году, когда в Китае свирепствовал тяжёлый острый респираторный синдром (严重 急性呼吸系统综合症), ВОЗ не стала называть грипп «китайским», чтобы не задеть чувства китайского народа и соблюсти все этические нормы, а приняла аббревиатуру SARS. Аналогичным образом ВОЗ объявила о коронавирусе - «新型冠状病毒》.

Итак, 新型冠状病毒 'коронавирусная инфекция нового типа' - это неологизм, образованный путём сложения трёх слов:

1) 新型 xīn xíng 'новый тип, новая модель, новый вид';

2) 冠状 xīn guān 'корональный, в форме короны';

3) 病毒 bìng dú 'вирус, вирусное заболевание'.

В таблице 1 представлены некоторые выражения, которые часто встречались с данным неологизмом в проанализированных статьях (перевод примеров наш - К. В., О. Т.).

Т а б л и ц а 1. Устойчивые выражения с неологизмом «коронавирус» [T a b l e 1. Set expressions with neologism "coronavirus"]

\begin{tabular}{|c|c|c|}
\hline Выражение & Транскрипция (пиньинь) & Перевод \\
\hline 防控新型冠状病毒 & Fángkòng xīnxíng guānzhuàng bìngdú & $\begin{array}{c}\text { Профилактика и контроль } \\
\text { коронавируса }\end{array}$ \\
\hline 冠病感染群 & Guānbìng gănrăn qún & Зараженная коронавирусом группа \\
\hline 冠病患者 & Guānbìng huànzhě & Больной коронавирусом \\
\hline 冠病病例 & Guānbìng bìnglì & Случаи заболевания коронавирусом \\
\hline 冠状病毒检测试剂 & Guānzhuàng bìngdú jiăncè shìjì & $\begin{array}{c}\text { Реагенты для обнаружения } \\
\text { коронавируса }\end{array}$ \\
\hline 冠状病毒抗体 & Guānzhuàng bìngdú kàngť̃ & Антитела к коронавирусу \\
\hline 冠状病毒的传染性 & Guānzhuàng bìngdú de chuánrănxìng & Контагиозность коронавируса \\
\hline
\end{tabular}


Следующий неологизм 宅家经济 'домашняя экономика' образован сложением двух слов:

1) 宅家 zháijiā 'дом, домашний';

2) 经济 jīngjì («экономика»).

Прежде всего речь идёт о том, что с момента введения полной изоляции во многих городах и районах Китая вся социальная активность человека была перенесена в квартиру или дом: сотрудники стали работать удалённо, школьники и студенты - заниматься в дистанционном режиме, даже занятия у детей дошкольного возраста начали проводиться в онлайн-формате. Но к чему здесь упоминание об экономической сфере? Дело в том, что подобный образ жизни в четырёх стенах невольно увеличил спрос на Интернет-услуги в несколько раз. Согласно последним данным, в Китае уже более 900 млн. интернет-пользователей.

В статье информационного агентства «Синьхуа» от 20 июля 2020 года под названием «Домашняя экономика»: какие ещё есть «окошки» для новых инвестиций?» подчёркивается, что «домашняя экономика» способствует увеличению прибыли предприятий. «Домашняя жизнь» приносит пользу многим отраслям. Количество пользователей программного обеспечения для удалённого офиса и обучения, такого как Dingding, Tencent Conference, BaiduNetdisk и Yuanjiao, резко возросло...» [Цзян, Ян, 2020 a].

Авторы статьи «Процветающая «домашняя экономика»: неожиданный подъём или будущие перспективы?» на эту же тему отмечают, что «домашняя экономика» знаменует новый этап цифровизации общества: «13 департаментов, включая Национальную комиссию по развитию и реформам, недавно объявили о поддержке здорового развития новых форм бизнеса и новых моделей, активизации потребительского рынка и стимулировании расширения занятости, включая 15 типов онлайн-образования, интернет-здравоохранения, онлайн-офисов и др» [Цзян, Ян, 2020 б].

Правительство в срочном порядке приступило к введению различных мер по борьбе с распространением коронавирусной инфекции в марте 2020 года. Соответственно, для обозначения данных мероприятий в китайском языке, как и в других языках, стали появляться неологизмы. Разумеется, основными источниками по-прежнему являются как общественно-политические СМИ, так и социальные сети.

Таким неологизмом стал 战疫 'война с эпидемией' / 'воевать с эпидемией'. В словаре современного китайского языка [Словарь, 2016] есть слово 阻击 zŭjīi, которое интерпретируется как «выслать подкрепление, бежать или атаковать, чтобы сдержать противника». В качестве примера приводится предложение: 疫情阻击战就是把病毒比 喻为敌人 - 'В борьбе за сдерживание эпидемической ситуации врагом выступает вирус', где «вирусное заболевание является метафорой «враг, враги». Неологизм 战疫 zhànyì 'война с эпидемией' - это омоним 战 役 zhànyі̀, который означает 'битва, операция, военная кампания'.

Необходимо отдельно упомянуть о том, что само слово 疫 'эпидемия' появилось в китайском языке с древнейших времён. В словаре «Шовэньцзецзы» (《说文解字》), или «Толкование самостоятельных смысловых единиц и разбор составных знаков», первом систематизированном словаре китайского языка (который актуален и поныне), выдающийся учёный периода Восточная Хань Сюй Шэнь (许 慎) писал о заразности чумы:

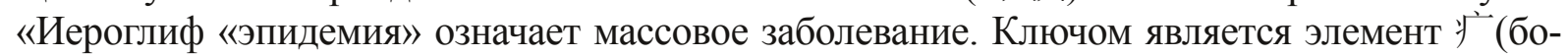
лезнь), а фонетиком - 役 уі̀ (《疫, 民皆疾也。从庐, 役省声》) [Шовэнь..., 2020].

Лю Си (刘 熙) в эпоху Восточная Хань в своём этимологическом словаре «Шимин» («释名») дал определение иероглифу 疫 как бедствию, возникшему в результате воздействия мистических сил. В условиях профилактики и контроля эпидемии часто стали применить иероглиф 疫 для замены омофонов в составе некоторых слов. Таким образом, получились совершенно новые слова и выражения. Рассмотрим следующий контекст: 
“疫”外收获：浙江公安一个月抓获在逃人员 678 名 - 'Сбор урожая, выходящего за рамки эпидемиологической профилактики и контроля: полиции провинции Чжэцзян в течение месяца удалось задержать 678 сотрудников офисов, нарушивших режим карантина (букв. находившихся в бегах)' [Го, Чжоу, 2020]. Как видно, в слове意 外 yìwài 'случайность, непредвиденный случай' иероглиф 意 уі̀ был заменён на омофон 疫 уі̀ 'эпидемия'.

В китайских социальных сетях можно встретить фразеологизмы с новым значением, в связи с тем, что в них произошла аналогичная замена на омофон 疫 (см. табл. 2).

\section{Т а б л и ц а 2. Изменение значения фразеологизмов с неологизмами [T a $\mathrm{b} 1 \mathrm{e}$ 2. Meaning change of phraseological units with neologisms]}

\begin{tabular}{|c|c|}
\hline Исходный фразеологизм & Фразеологический неологизм \\
\hline $\begin{array}{c}\text { 一意孤行 yīyì gūxíng 'действовать самовольно, } \\
\text { не считаясь с мнением других' }\end{array}$ & $\begin{array}{c}\text { 一疫孤行 yīyì gūxíng («если заболел, то следует } \\
\text { изолироваться, нельзя контактировать с людьми») [Mа, } \\
\text { 2020] }\end{array}$ \\
\hline $\begin{array}{c}\text { 麻痹大意 mábì dàyì 'потерять бдительность; } \\
\text { ротозейничать' }\end{array}$ & $\begin{array}{c}\text { 麻㿎大疫 mábì dàyì («халатное отношение к мерам } \\
\text { профилактики, которое приводит к крупным вспышкам } \\
\text { заражений») [Baidu, 2020] }\end{array}$ \\
\hline $\begin{array}{c}\text { 薄情寡义 baóqíng guăyì 'бездушный, досл. } \\
\text { чувство равнодушия и заниженное чувство } \\
\text { долга' }\end{array}$ & $\begin{array}{c}\text { 薄情寡疫 baóqíng guǎyì («настроить себя на то, чтобы } \\
\text { не ходить в гости и не контактировать с людьми, тем } \\
\text { самым снизить риски заражения») [ Ли Тун,2020] }\end{array}$ \\
\hline $\begin{array}{c}\text { 艺不压身 yìbù yāshēn 'мастерство на плечи не } \\
\text { давит' }\end{array}$ & $\begin{array}{c}\text { 疫不压身 yìbù yāshēn («эпидемия не продавит нас») } \\
\text { [Эпидемия..., 2020] }\end{array}$ \\
\hline
\end{tabular}

Анализируя неологизм 战疫 'война с эпидемией' / 'воевать с эпидемией', важно отметить, что это новое слово может употребляться и как существительное, и как глагол. Например: 《金银潭医院是这场战“疫”中，最早收治、收治病人最多的“主战场”'Во время войны с пандемией больница «Цзиньиньтань» стала главным местом сражений, так как самая первая начала принимать самое большое количество больных' [Тан и др., 2020]. В этом примере неологизм 战疫 употреблён как существительное, к нему относится такое же именное счётное слово场, как и для слова 战 'война, военное действие'. Этот же неологизм战疫 выполняет роль глагола в заголовке статьи «老党员发动, 儿孙齐战“疫》 'Пожилые члены партии выступают с инициативой, а дети и внуки приведут в порядок войну с эпидемией' [Ли Ган, 2020].

До 2019 года были известны лишь единичные случаи появления данного неологизма на страницах СМИ Китая. Например, удалось найти всего одну статью за 2013 год в журнале «Наньфэнчуан» (南风窗): 《离流感战 “疫” ，应急得与失》-'Война с эпидемией «птичьего гриппа», экстренный случай - приобретения и потери', что объясняется не столь глобальным характером заболеваний. В период пандемии коронавируса неологизм употребляется всё чаще и чаще, и некоторые лингвисты, журналисты, комментаторы Китая делают предположения о том, что, спустя определённый период времени, данный неологизм обязательно войдёт в список общеупотребительных [Ду, 2020].

Неологизм封城 представляет собой сокращённую версию нового словосочетания 封锁城市 'закрытый город / закрыть город' или 'изолироваться'. В период коронавируса в СМИ появляется много статей о том, где вводится режим карантина или самоизоляции с целью сдержать распространение болезни. Неологизм образован соединением двух первичных слов:

1) 封 fēng 'плотно закрывать, запирать, запечатывать, закупоривать, опечатывать, блокировать';

2) 城 chéng 'город, городская стена, территория города'. 
По аналогии были образованы неологизмы 封村 'закрытая деревня / закрыть деревню', 封区 'закрытый район / закрыть район' и т. д.

Одна из самых значимых статей вышла в апреле 2020 года в «ChinaDaily» под заголовком «11 миллионов человек приостановили свой путь. От закрытия до открытия. Что пережил Ухань за 76 дней?». В статье подробно описывается героизм и стойкость жителей Уханя, самоотверженность врачей и волонтеров, строгое соблюдение карантинных мер [Лю, 2020]. В тексте статьи мы встречаем неологизм 解封城 'освобождение города / открывать город', который является антонимом предыдущего неологизма.

Неологизм 社交距离 'социальная дистанция', соединивший два слова: 1) 社交 shèjiāo 'общественный, знакомства, социальный', 2) 距 离 jùlí 'расстояние, дальность, дистанция', является заимствованием, образованным гибридным способом. Отметим, что, во-первых, словосочетание имеет схожесть в звучании с английским словом social 'общественный, социальный', а во-вторых, каждый иероглиф имеет своё собственное значение. Очевидно, что данный термин не является новым, и до разразившейся пандемии коронавирусной инфекции данное словосочетание использовалось, однако с 2020 года определение термина «социальная дистанция» приобрело несколько иное значение. Буквально до 2019 году под этим понятием подразумевали соблюдение дистанции от окружающих, равной длине вытянутой руки, и минимизацию массовых скоплений людей. С начала 2020 года - «избегание общественных мест, массовых собраний, мероприятий, поддержка дистанции в 2 метра от других людей» [Как защитить себя и других, 2020]. Наиболее часто употребляемые фразы с неологизмом «социальная дистанция» в таблице 3.

Т а б л и ц а 3. Устойчивые выражения с неологизмом «социальная дистанция» [T a b 1 e 3. Set expressions with neologism "social distance"]

\begin{tabular}{|c|c|c|}
\hline Выражение & Транскрипция (пиньинь) & Перевод \\
\hline 保持社交距离 & Băochí shèjiāo jùlí & Соблюдать социальную дистанцию \\
\hline 安全社交距离 & ānquán shèjiāo jùlí & Безопасная социальная дистанция \\
\hline 社交距离措施 & Shèjiāo jùlí cuòshī & Меры соблюдения социальной дистанции \\
\hline 规定社交距离 & Guīdìng shèjiāo jùlí & Установить социальную дистанцию \\
\hline
\end{tabular}

Другое новое словосочетание, появившееся в 2020 г. - это 无接触配送 'бесконтактная доставка' - образовано сложением двух слов:

1) 无接触 wújiēchù («бесконтактный);

2) 配送 pèisòng («рассылка, доставка, поставка»).

В статье 《快递外卖 “无接触配送” 标准实施》'Внедрение стандарта 《бесконтактной доставки» для экспресс-доставки', опубликованной на сайте «Синьхуа» в марте 2020 года, как раз сообщается о том, что новая форма или модель доставки товаров является обязательной и повсеместной [Чжан, 2020].

Неоспорим тот факт, что изоляция, в которой находились люди разных стран в одно время, может привести (и уже приводит) к тяжёлым психологическим последствиям: от повышенного уровня тревожности, бессонницы и эмоциональной нестабильности до посттравматического синдрома (ПТСР) и депрессии. В лексике китайского языка закономерно появляются неологизмы с негативной коннотацией. В исследуемом материале таких два: 信息疫情 xìnxī yìqíng 'информационная пандемия' ('инфодемия') и 你别来我无恙 nǐ biélái wǒ wúyàng 'Не надо приходить, я в порядке'. 
信息疫情 'информационная пандемия' ('инфодемия') - это неологизм, которым характеризуют на страницах общественно-политических изданий слухи и дезинформацию о коронавирусе. Образован сочетанием двух слов:

1) 信息 xìnxī 'информация, сведения, известия, сообщения';

2) 疫情 yìqíng 'эпидемическая ситуация (обстановка); эпидемия, пандемия'.

В статье 《信息疫情” 是全球携手抗疫的更大挑战》'《Информационная пандемия» представляет собой более серьёзный вызов в глобальной борьбе с эпидемией' подробно описаны причины появления ложной информации. Во-первых, человечество столкнулось с абсолютно новым видом вируса, поэтому медицинское сообщество не выработало действенного оружия против него. Следовательно, рождаются всё новые слухи и ложные утверждения, умозаключения, наблюдается процесс мистификации. Во-вторых, эпидемия новой коронной пневмонии носит агрессивный, сложный и крайне опасный характер, сея огромную панику в человеческом обществе. В-третьих, бездействие политиков, уход чиновников от ответственности, умалчивание реальных статистических данных - всё это порождает новые слухи и домыслы.

«Информационная пандемия» - характерная черта современного мира. Интернет-технологии меняются с каждым днём. Широко используются различные новые медиаресурсы и социальное программное обеспечение. В определённой степени каждый может стать создателем новостей, информации, и люди полностью открыты для различных информационных потоков», - делают заключения авторы статьи, Ван Лэй и Чэн Цинвэнь [Ван, Чэнь, 2020].

Новое выражение 你别来我无恙 nǐ biélái wǒ wúyàng 'Не надо приходить, я в порядке' является производным от известного выражения别来无恙 'Сколько лет, сколько зим!' (досл. 'Все ли в порядке с момента разлуки?') как одной из форм приветствия. Изначально коннотация выражения положительная, но в период пандемии коронавируса форма выражения изменилась и приобрела негативный оттенок. Позитивная коннотация базируется на таком значении как 'забота о близких и родных'. В статье о главном китайском празднике Чуньцзе (Празднике Весны), автор Хао Сысы (郝思斯) пишет: 此 时的不回乡是一种孝顺, 此时的不出门是一种定力, 此时的不聚会是一种修养, 此时 的不见面是一种科学 [Хао, 2020]- 'Не навещать отчий дом в это время - это своего рода проявление сыновьей почтительности, не выходить на улицу в это время - это своего рода решительность, не собираться в это время - это своего рода воспитание характера, не встречаться в это время - это целая наука'. Негативная же коннотация выражается в том, что говорящий, боясь заразиться от собеседника, то есть потенциального переносчика инфекции, может довольно резко оборвать всякое общение. Прежде всего это, конечно, передаётся интонационно. В статье «Неологизмы, которые появились в период коронавируса» сообщается, что «эта дань истории, которая, казалось бы, выглядит довольно забавно, однако может принимать вполне грубую форму. Например: «Если ты вообще хочешь, чтобы я нормально жил, просто держись подальше!» [Чэн, 2020].

В завершение данного раздела проанализируем ещё один интересный неологизм: 抄作业 chāozuòyè 'списывать домашнюю работу', состоящий из двух слов:

1) 抄 chāo 'переписывать, копировать, совершать плагиат, списать';

2) 作业 'домашнее задание, работать, действовать'.

Новое значение, которое приобрело данное выражение в период пандемии Covid-19 - копировать действия Китая в борьбе с коронавирусной инфекцией нового типа. Впервые данный неологизм появился в статье от 23 марта 2020 года 美国开始抄 作业! 加州、华盛顿多地建方舱, 收治新冠肺炎患者 - 'США начинают копировать домашнее задание! В Калифорнии и Вашингтоне построены приюты из модульных блоков-контейнеров для пациентов с новой коронарной пневмонией'. В статье сообщается о том, что в конце марта Соединённые Штаты побили мировой рекорд по заражению 
коронавирусом. С целью сдержать распространение болезни американское правительство предпринимает те же действия, что и китайское в декабре-январе: отменяют все массовые мероприятия, учёба и работа переводится в дистанционный формат, многие крупные здания переоборудуются под больницы для приёма больных людей и т. д. [Цзяцзы, 2020].

\section{3. Заключение [Conclusion]}

В период глобализации вслед за развитием всех сфер жизни общества активно меняется и лексический состав языка. Проведённое исследование позволило продемонстрировать 10 самых частотных из более чем 30 обнаруженных неологизмов, реализованных в 289 контекстах, которые возникли в китайском языке во время пандемии коронавирусной инфекции.

Как и все неологизмы, они выполняют важную роль пополнения словарного запаса современного китайского языка. Результаты, представленные в настоящей статье, показали, как уже имеющиеся в языке слова приобретают новые лексические значения и как могут адаптироваться заимствования, приобретая свойственную китайскому языку-реципиенту фонетическую форму и грамматические признаки.

По нашим подсчётам частоты употребления 10 неологизмов в текстах общественно-политических СМИ Китая вырисовывается следующая картина: 新型冠状病毒 xīnxíng guānzhuàng bìngdú 'коронавирусная инфекция нового типа' - ранг 1 (78 контекстов); 社交距离 shèjiāo jùlí 'социальная дистанция' - ранг 2 (52 контекста); 封 城 fēng chéng 'закрытый город / закрыть город' или 'изолироваться' - ранг 3 (40 контекстов); 解封 城 jiěfēng chéng 'освобождение города / открывать город' - ранг 4 (36 контекстов); 无接触 配送 - ранг 5 (26 контекстов); 你别来我无恙 nǐ biélái wǒ wúyàng 'Не надо приходить, я в порядке' - ранг 6 (19 контекстов); 宅家 经 济 zháijiā jīngjì 'домашняя экономика' - ранг 7 (12 контекстов); 信息疫情 xìnxī yìqíng 'информационная пандемия' ('инфодемия') - ранг 7 (12 контекстов); 战疫 zhànyì 'война с эпидемией' - ранг 9 (9 контекстов); 抄作业 chāozuòyè 'списывать домашнюю работу' - ранг 10 (5 контекстов).

В ходе исследования материала выявлено, что самым распространённым способом образования неологизмов оказалось словосложение (60\% неологизмов): зафиксировано сложение вторичных слов (чаще), а также первичных слов друг с другом и первичных со вторичными. Кроме того, показано, что для образования неологизмов использовались возможности омофонии, но этот способ встречается реже всего (10\%). Последний зафиксированный способ - приобретение дополнительной (добавочной) коннотации, когда форма слова остаётся прежней, а в семантической структуре происходит процесс переосмысления и расширения значения - всего встретилось $30 \%$ от общего числа рассмотренных неологизмов.

\section{Библиографический список}

Горелов, 1984 - Горелов В. И. Лексикология китайского языка : учеб. пособие. М. : Просвещение, 1984. $216 \mathrm{c}$.

Дубинина, 2021 - Дубинина М. Н. Семантический анализ лозунгов эпохи пандемии в Китае // Филологические науки. Вопросы теории и практики. 2021. Т. 14, Вып. 2. С. 475-483.

Касьянова, 2009 - Касьянова Л. Ю. Когнитивно-дискурсивные проблемы неологизации в русском языке конца XX - начала XXI века : дис. ... д-ра филол. наук : 10.02.01 / Касьянова Людмила Юрьевна ; Астраханский гос. ун-т. Астрахань, 2009. 401 с.

Ли Синь, Стародубцева, 2021 - Ли Синь, Стародубцева Н. С. Лозунги на работах мастеров нематериального культурного наследия Китая как средство борьбы с эпидемией коронавирусной инфекции (COVID-19) // Теоретическая и прикладная лингвистика. 2021. Вып. 7, № 3. C. 116-130. doi : 10.22250/24107190_2021_7_3_116_130. 
Шамина и др., 2020 - Шамина Е. А., Беседина Е. И., Кузьмич И. В. Современный англоязычный дискурс в условиях пандемии: методический потенциал // Теоретическая и прикладная лингвистика. 2020. Вып. 6, № 4. С. 170-181. doi : 10.22250/2410-7190_2020_6_4_170_181.

Ван, Чэнь, 2020 - 王否, 陈倩文. 《信息疫情》是全球携手抗疫的更大挑战 // 光明思想理论网 [Ван Лэй, Чэнь Цинвэнь. «Информационная пандемия» представляет собой более серьезный вызов в глобальной борьбе с эпидемией // Теория мысли Гуанмин : офиц. сайт]. URL : https://theory.gmw.cn/2020-05/11/content 33821286.htm (дата обращения: 18.11.2020).

Ван, 1991 - 王铁琨. 十年来的汉语新词语研究//语文建设通讯. 1991 年. 第 4 期. 第 9-13 页 [Ван Текунь. Исследование неологизмов китайского языка в последние десятилетия // Языковое планирование. 1991. № 4. С. 9-13].

Го, Чжоу, 2020 - 郭扬, 戴谦. “疫” 外收获: 浙江公安一个月抓获在逃人员 678 名 // 人民网 [Го Ян, Чжоу Ван. Сбор урожая, выходящего за рамки эпидемиологической профилактики и контроля: полиции провинции Чжэцзян в течение месяца удалось задержать 678 сотрудников офисов, нарушивших режим карантина // Газета «Жэньминь»: офиц. сайт]. URL: http:// zj.people.com.cn/n2/2020/0229/c228592-33838227.html (дата обращения : 18.11.2020).

Ду, 2020 - 杜翔. “战疫”的造词理据 //光明日报 [Ду Сян. Мотивация для борьбы с эпидемией // Газета «Гуанмин жибао»: офиц. сайт]. URL : https://news.gmw.cn/2020-03/21/ content_33670745.htm (дата обращения : 18.11.2020).

Дяо, 2003 - フ宴斌. 近 10 年新词语研究述评 // 辽宁师范大学学报. 2003 年。第 1 期. 第 4-10 页 [Дяо Яньбинь. Обзор неологизмов, возникших за последние 10 лет // Вестник Ляонинского пед. ун-та. 2003. № 1. С. 4-10].

Как защитить себя и других, 2020 - 如何保护自己和他人 // CDC [Как защитить себя и других // Центр по контролю и профилактике Covid-19: офиц. сайт]. URL: https://chinese.cdc.gov/ coronavirus/2019-ncov/prevent-getting-sick/social-distancing.html (дата обращения : 18.11.2020).

Ли Ган, 2020 - 李刚. 广州市从化区良口镇米埗村一一老党员发动儿孙齐战 “疫” //乡村干部 报 [Ли Ган. Деревня Мибу, город Лянкоу, район Цунхуа, город Гуанчжоу - пожилые члены партии выступают с инициативой, а дети и внуки приведут в порядок войну с эпидемией// Газета активистов деревни: офиц. сайт]. URL : http://www.xcgbb.com/zt/zyfy/ds/202002/ t20200211_6504987.shtml (дата обращения : 18.11.2020).

Ли Тун, 2020 - 李童. 面对薄情寡疫, 我们以独攻毒 / 凤凰网 [Ли Тун. Перед лицом пандемии мы противоборствуем в одиночку // Телевидение «Феникс»: офиц. сайт]. URL : http:// hebei.ifeng.com/a/20200221/8439726_0.shtml (дата обращения : 18.11.2020).

Лин, Лю, 2020 - 凌馨，刘曲. 世卫组织将新冠肺炎命名为“COVID-19”// 中华人民共和国中央人 民政府 [Лин Синь, Лю Цюй. ВО3 назвал новую коронавирусную инфекцию “COVID-19” // Центральное народное правительство КНР: офиц. сайт]. URL: http://www.gov.cn/xinwen/ 2020-02/12/content_5478891.htm (дата обращения : 18.11.2020).

Лю, 2020 - 刘军. 1100 万人暂停轨迹, 从封城到解封, 武汉 76 天经历了什么? // 中国日报 [Лю Цзюнь. 11 миллионов человек «проделали» свой путь от изоляции до освобождения, что пережил Ухань за 76 дней? // Чайна дейли: офиц. сайт]. URL : http://cn.chinadaily.com.cn/ a/202004/08/WS5e8db15ca310395ca8f747b3.html (дата обращения : 18.11.2020).

Мa, 2020 -马奎荣. 铁路的一 “疫” 孤行, 带去了人民的关心 // 中国山东网 [Ма Куйжун. «Эпидемия» железной дороги пошла своим путем, что вызвало обеспокоенность людей // Шаньдун (Китай): офиц. сайт]. URL: http://news.sdchina.com/show/4484210.html (дата обращения : 18.11.2020).

Словарь..., 2016 - 现代汉语词典/北京: 商务印书馆, 2016 年, 1894 页. [Словарь современного китайского языка. Пекин : Изд-во «Коммерческая пресса», 2016. 1894 с.].

Тан и др., 2020 - 唐卫彬、廖君、屈婷、李劲峰、黎昌政. 武汉, 负重前行// 人民网 [Тан Вэйбинь, Ляо Цзюнь, Цюй Тин, Ли Цзиньфэн, Ли Чанчжэн. Ухань, ты справишься с этими трудностями // Газета «Жэньминь» : офиц. сайт]. URL : http://paper.people.com.cn/rmrb/html/ 2020-01/31/nw.D110000renmrb_20200131_5-04.htm (дата обращения : 18.11.2020).

Xao, 2020 - 郝思斯. 字里行间 | 别来无恙: 你别来, 我无恙 // 中央纪委国家监委网站 [Xao Сысы. Между строк: не подходи и будь в безопасности; не подходи, я в порядке // Гос.контрольный комитет ЦКПД : офиц. сайт]. URL : http://www.ccdi.gov.cn/toutiao/202001/ t20200130_210532.html (дата обращения : 18.11.2020). 
Цзян, Ян, $2020 \mathrm{a}$ - 姜琳、阳建. 宅经济” : 还会有哪些投资新 “风口 // 新华网 [Цзян Линь, Ян Цзянь. «Домашняя экономика»: какие еще есть «окошки» для новых инвестиций? // ИА «Синьхуа» : офиц. сайт]. URL : http://www.xinhuanet.com/fortune/2020-07/20/c_1126258998.htm (дата обращения : 18.11.2020).

Цзян, Ян, 2020 б-姜琳、阳建. 火红 “宅经济” : 意外崛起还是未来趋势? //新华网 [Цзян Линь, Ян Цзянь. «Процветающая «домашняя экономика»: неожиданный подъем или будущие перспективы? // ИА «Синьхуа»: офиц. сайт]. URL: http://www.xinhuanet.com/ fortune/2020-07/19/c_1126257572.htm (дата обращения : 18.11.2020).

Цзяцзы, 2020 - 甲子光年. 美国开始抄作业! 加州、华盛顿多地建方舱, 收治新冠肺炎患者 // 百度 [Цзяцзы Гуаннянь. США начинает копировать меры по борьбе с коронавирусом! В Калифорнии и Вашингтоне построены приюты для пациентов с новой коронарной пневмонией // Байду : офиц. сайт]. URL : http://baijiahao.baidu.com/s?id=1661965329855748056 (дата обращения : 18.11.2020).

Чжан, 2020 - 张楠. 快递外卖 “无接触配送” 标准实施 // 新华网 [Чжан Нань. Внедрение стандарта «бесконтактной доставки» для экспресс-доставки // ИА «Синьхуа» : офиц. сайт]. URL : http://www.xinhuanet.com/info/2020-03/17/c_138885850.htm (дата обращения : 18.11.2020).

Чэн, 2020 - 程千千. 新冠疫情下涌现的新词: Covidiot、抄作业//澎看新闻 [Чэн Цяньцянь. Неологизмы, которые появились в период коронавируса: ковидиот, списывать домашнюю работу... // Пэнпай : офиц. сайт]. URL : https://m.thepaper.cn/rss_newsDetail_7045808?from= (дата обращения : 18.11.2020).

Чэнь, 1999 - 陈原. 语言与社会生活/北京: 生活. 读书. 新知三联书店, 1999 年, 122 页. [Чэн Юань. Язык и общественная жизнь. Пекин: Совместная издательская компания «Жизнь. Чтение. Новые знания», 1999. 122 с.].

Шовэнь..., 2020 - 说文解字 [Шовэнь цзецзы] : сайт. URL : https://ctext.org/shuo-wen-jie-zi/zhs (дата обращения : 18.11.2020).

Эпидемия..., 2020 - “疫” 不压身, 建筑学院线上教学总有一 “招” 吸引你 // 哈工大 [«Эпидемия» не сокрушает ваше тело, в онлайн-обучении школы архитектуры всегда есть «уловка», чтобы привлечь вас // Харбинский технол. ин-т: офиц. сайт]. URL: http:// www.hitsz.edu.cn/article/view/id-84641.html (дата обращения : 18.11.2020).

Яо, 1998 - 姚汉铭. 新词语. 社会. 文化/ 上海：上海辞书出版社, 1998 年, 228 页. [Яо Ханьмин. Новые выражения. Общество. Культура. Шанхай : Шанхайское лексикографическое изд-во, 1998. 228 c.].

\section{References}

Gorelov, V. I. (1984). Leksikologiya kitayskogo yazyka [Chinese lexicology]. Moscow : Prosveshhenie Press. (In Russ.).

Dubinina, M. N. (2021). Semanticheskiy analiz lozungov epokhi pandemii v Kitae [Semantic analysis of slogans during the pandemic in China]. Filologicheskie nauki. Voprosy teorii i praktiki [Philology. Theory \& Practice], 14 (2), 475-483. (In Russ.).

Kas'yanova, L. Y. (2009). Kognitivno-diskursivnye problemy neologizatsii v russkom yazyke kontsa $X X$-nachala XXI veka [Cognitive-discursive problems of neologization in the Russian language of the late XX - early XXI centuries]. PhD in Philological sci. diss. Astrakhan : Astrakhan State University. (In Russ.).

Li Xin, Starodubtseva, N. S. (2021). Lozungi na rabotakh masterov nematerial'nogo kul'turnogo naslediya Kitaya kak sredstvo bor'by s epidemiey koronavirusnoy infektsii (COVID-19) [Slogans on the works of masters of China's intangible cultural heritage as a means of combating the epidemic of coronavirus infection (COVID-19)]. Teoreticheskaya i prikladnaya lingvistika [Theoretical and Applied Linguistics], 7 (3), 116-130. doi: 10.22250/2410-7190_2021_7_3_116_130. (In Russ.).

Shamina, E. A., Besedina, E. I., Kuzmich, I. V. (2020). Sovremennyy angloyazychnyy diskurs v usloviyakh pandemii: metodicheskiy potentsial [Contemporary English language discourse during the pandemic: Methodological potential]. Teoreticheskaya i prikladnaya lingvistika [Theoretical and Applied Linguistics], 6 (4), 170-181. doi : 10.22250/2410-7190_2020_6_4_170_181. (In Russ.). 
Wáng Lěi, Chén Qiànwén. (2020). Xìnxī yìqíng» shì quánqiú xiéshǒu kàng yì de gèng dà tiăozhàn// Guāngmíng sīxiăng lìtùn wăng [«Information Epidemic» A greater challenge for the global fight against the epidemic. Thought theory of Guangming]. Retrieved November 18, 2020 from $<\mathrm{https}$ :// theory.gmw.cn/2020-05/11/content_33821286.htm>. (In Chinese).

Wáng Tiěkūn. (1991). Shí niánlái de hànyǔ xīn cíyǔ yánjiū [Investigation of neologisms of the Chinese language in recent decades]. Yǔwén jiànshè tōngxùn [Language planning], 4. 9-13. (In Chinese).

Guō Yáng, Dài Qiān. (2020). "Yì” wài shōuhuò: Zhèjiāng gōng'ān yīgè yuè zhuāhuò zàitáo rényuán 678 míng [Harvest outside the "epidemic": Zhejiang police arrested 678 fugitives in one month]. Rénmín wăng [People's Daily Online]. Retrieved November 18, 2020 from <http:// zj.people.com.cn/n2/2020/0229/c228592-33838227.html>. (In Chinese).

Dù Xiáng. (2020). “Zhàn yì” de zào cí lịjù [Reasons for "War Epidemic"]. Guāngmíng rìbào [Guangming Daily]. Retrieved November 18, 2020 from <https://news.gmw.cn/2020-03/21/ content_33670745.htm >. (In Chinese).

Diāo Yànbīn. (2003). Jìn 10 nián xīn cíyǔ yánjiū shùpíng [Review of neologisms that have arisen over the past 10 years]. Liáoníng shïfàn dàxué xuébào [Journal of Liaoning Normal University], 1. 4-10. (In Chinese).

Rúhé... (2020). Rúhé băohù zìjǐ hé tārén [Keep social distance]. CDC [Centers for Disease Control and Prevention]. Retrieved November 18, 2020 from < https://chinese.cdc.gov/coronavirus/2019-ncov/ prevent-getting-sick/social-distancing.html>. (In Chinese).

Lǐ Gāng. (2020). Guăngzhōu shì cónghuà qū liáng kǒu zhèn mǐ bù cūn — lăo dăngyuán fādòng érsūn qí zhàn "yì” [Mibu Village, Liangkou Town, Conghua District, Guangzhou City-Old party members launched their children and grandchildren to fight the "epidemic"]. Xiāngcūn gànbù bào [The Village Cadre]. Retrieved November 18, 2020 from <https:/www.gdzz.gov.cn/dyjy/xjdx/content/ post_4000.html >. (In Chinese).

Lǐ Tóng. (2020). Miàn duì bóqíng guăyì, wǒmen yǐdú gōngdú [Faced with the pandemic, we fight alone]. Fènghuáng wăng [Phoenix Television]. Retrieved November 18, 2020 from <http:// hebei.ifeng.com/a/20200221/8439726_0.shtml>. (In Chinese).

Líng Xīn, Liú Qū. (2020). Shìwèi zǔzhī jiāng xīnguān fèiyán mìngmíng wèi “COVID-19” [Who names new type of coronavirus pneumonia "COVID-19"]. Zhōnghuá rénmín gònghéguó zhōngyāng rénmín zhèngfú [The Central People's Government of the People's Republic of China]. Retrieved November 18, 2020 from <http://www.gov.cn/xinwen/2020-02/12/content_5478891.htm >. (In Chinese).

Liú Jūn. (2020). 1100 Wàn rén zàntíng guǐjīị, cóng fēng chéng dào jiě fēng, wǔhàn 76 tiān jīnglìle shénme? [11 million people suspended their trajectory. From the lockdown to the release, what has Wuhan experienced in 76 days?]. Zhōngguó ribào [China Daily]. Retrieved November 18, 2020 from <http:// cn.chinadaily.com.cn/a/202004/08/WS5e8db15ca310395ca8f747b3.html >. (In Chinese).

Mă Kuíróng. (2020). Tiělù de ȳ̄ "yì” gūxíng, dài qùle rénmín de guānxīn [The "epidemic" of the railway drove the people's concern]. Zhōngguó shāndōng wăng [China Shandong Net]. Retrieved November 18, 2020 from <http://news.sdchina.com/show/4484210.html>. (In Chinese).

Xiàndài hànyǔ cídiăn [Contemporary Chinese Dictionary]. (2016). Beijing: Shāngwù yìn shūguăn. (In Chinese).

Tang Weibin, Liao Jun, Qu Ting, Li Jinfeng, Li Changzheng. (2020). Wǔhàn, fùzhòng qián xíng [Wuhan, you cope with these troubles]. Rénmín wăng [People's Daily Online]. Retrieved November 18, 2020 from <http://paper.people.com.cn/rmrb/html/2020-01/31/nw.D110000renmrb_20200131_5-04.htm>. (In Chinese).

Hăo Sīsī. (2020). Zìlǐhángjiān | bié lái wúyàng: Nǐ bié lái, wǒ wúyàng [Between the lines | Don't come and be safe: Don't come, I'm safe]. Zhōngyāng jìwěi guójiā jiān wěi wăngzhàn [Central Commission for Discipline Inspection and State Supervision Commission]. Retrieved November 18, 2020 from <http://www.ccdi.gov.cn/toutiao/202001/t20200130_210532.html>. (In Chinese).

Jiāng Lín, Yáng Jiàn. (2020 a). Zhái jīngjì: Hái huì yǒu năxiē tóuzī xīn "fēngkǒu ["House economy": what other new investment "outlets"]. Xīnhuá wăng [Xinhuanet]. Retrieved November 18, 2020 from <http:/www.xinhuanet.com/fortune/2020-07/20/c_1126258998.htm>. (In Chinese). 
Jiāng Lín, Yáng Jiàn (2020 b). Huǒhóng "zhái jīngji”: Yìwài juéqĩ háishì wèilái qūshì? [Flaming "home economy": unexpected rise or future trend?]. Xīnhuá wăng [Xinhuanet]. Retrieved November 18, 2020 from <http://www.xinhuanet.com/fortune/2020-07/19/c_1126257572.htm>. (In Chinese).

Jiăzǐ Guāngnián (2020). Měiguó kāishǐ chāo zuòyè! Jiāzhōu, huáshèngdùn duō de jiàn fāng cāng, shōuzhì xīnguān fèiyán huànzhě [The United States starts copying homework! Shelter cabins built in California and Washington to treat patients with new coronavirus pneumonia]. Băidù. Retrieved November 18, 2020 from <http://baijiahao.baidu.com/s?id=1661965329855748056>. (In Chinese).

Zhāng Nán. (2020). Kuàidì wàimài "wú jiēchù pèisòng" biāozhǔn shíshī [Implementation of the "Contactless Delivery" standard for express delivery]. Xïnhuá wăng [Xinhuanet]. Retrieved November 18, 2020 from <http://www.xinhuanet.com/info/2020-03/17/c_138885850.htm>. (In Chinese).

Chéng Qiānqiān. (2020). Xīnguān yìqíng xià yǒngxiàn de xīn cí: Covidiot, chāo zuòyè... [New words emerging under the pandemic coronavirus: Covidiot, copy homework...]. Péngpài xīnwén [The Paper]. Retrieved November 18, 2020 from <https://m.thepaper.cn/rss_newsDetail_7045808? from $=>$. (In Chinese).

Chén Yuán. (1999). Yǔyán yǔ shèhuì shēnghuó [Language and social life]. Beijing: Shēnghuó •dúshū•xīnzhī sānlián shūdiàn. (In Chinese).

Shuōwén jiězì. Retrieved November 18, 2020 from <https://ctext.org/shuo-wen-jie-zi/zhs>. (In Chinese).

Yì (2020). "Yî" bù yā shēn, jiànzhú xuéyuàn xiàn shàng jiàoxué zǒng yǒuyī "zhāo" xīy̌̌n nǐ [The "epidemic" does not crush your body, there is always a trick to attract you]. Hāgōngdà [Harbin Institute of Technology [site]]. Retrieved November 18, 2020 from <http://www.hitsz.edu.cn/ article/view/id-84641.html>. (In Chinese).

Yáo Hànmíng. (1998). Xīn cíyǔ. Shèhuì. Wénhuà [New expressions. Society. Culture]. Shanghai : Shànghăi císhū chūbăn shè. (In Chinese).

Статья поступила в редакцию 26.11.2020; одобрена после рецензирования 03.10.2021; принята к публикации 03.11.2021.

The article was submitted 26.11.2020; approved after reviewing 03.10.2021; accepted for publication 03.11.2021. 